\title{
Higher Order Thinking Skills for Improved Learning Outcomes Among Indonesian Students: A Blended Web Mobile Learning (BWML) Model
}

\author{
https://doi.org/10.3991/ijim.v15i07.17909 \\ Bambang Hariadi $\left.{ }^{凶}\right)$, M. J. Dewiyani Sunarto, Tri Sagirani, \\ Tan Amelia, Julianto Lemantara \\ Dinamika University, Surabaya, Indonesia \\ bambang@dinamika.ac.id \\ Binar Kurnia Prahani, Budi Jatmiko \\ Surabaya State University, Surabaya, Indonesia
}

\begin{abstract}
This research aims to produce a model that can be used as a reference in implementing hybrid learning and Problem Based Learning (PBL) in learning with the MoLearn application. This research is a research development namely building the right learning model for the MoLearn application. The Blended Web Mobile Leaning (BWML) model test was conducted regarding its validity and practicality. The results showed that (1) test the content validity: the average statistic was 3.72 ralpha $=.25$ and alpha $=.81$ the construct validity: the average was 3.74 , the statistic was ralpha $=.20$ and alpha $=.75$. (2) the feasibility test (practically used by students) an average of 3.23 statistics ralpha $=.91$ and alpha $=.99$. It can be concluded that the BWML model meets the valid requirements (in content and construction), and is practical in use by students. This research implies that the quality BWML model can be used to improve learning outcomes for high school students based on higher-order thinking skills (HOTs). Further research can be focused on seeing the effectiveness of the BWML model in improving the learning outcomes of HOTs-based high school students.
\end{abstract}

Keywords - Higher-order thinking skills, blended web mobile learning, learning outcomes.

\section{Introduction}

Important problems are facing the world of education in Indonesia today, namely how to seek Higher Order Thinking Skills (HOTs) based learning outcomes improvement [1-5]. HOTs-based learning outcomes are student learning outcomes that involve high-level cognitive thinking activities from Bloom's taxonomy. Based on Bloom's taxonomic hierarchy, HOTs-based learning outcome indicators include analyzing, evaluating, and creating [6]. HOTs-based learning outcomes are very 
important because they provide superior student competencies to compete in the era of industrial revolution 4.0 and the demands of 21 st-century learning.

On the other hand, $21^{\text {st }}$ century learning emphasizes the existence of learning innovations, including critical thinking skills, problem-solving skills, literacy, collaboration, decision making, creative thinking, responsibility, and being able to learn independently [1] [7-9]. Martin's research results, [10] show that on average Indonesian students are only able to recognize some basic facts and are not yet able to communicate and connect various topics, especially in applying complex and abstract concepts. The survey results show that the average score of student achievement is below the average international score. In line with the survey conducted by TIMSS, the survey conducted by the Program for International Student Assessment (PISA) the average achievement score at the HOTs level in Indonesia is still far below the international average. This fact is in line with the results of research [1-3] [5] that the learning process is still a teacher center and emphasizes more on the process of transferring knowledge.

The low learning outcomes of HOTs-based high school students are thought to have something to do with the learning process and model used. The learning model used is the conventional learning model. This model is considered unable to facilitate the development of HOTs-based high school student learning outcomes [1-3] [5].

The PBL model can improve HOTs [11-20]. However, the PBL model is need to improve inquiry orientation, training student discipline, and authentic problems are still more challenging [14] [21-23]. Therefore, it is still necessary to improve and refine the PBL model to improve the learning outcomes of HOTs-based high school students.

Model Hybrid Learning is learning to provide the contents of a learning model in various media to keep up with current learning needs [24]. The application of Hybrid Learning can improve HOTs-based high school student learning outcomes but still needs improvement [24]. Models Hybrid Learning and Model PBL able to motivate students to conduct investigations and problem-solving in real-life situations and stimulate students to produce a product in improving learning outcomes based on HOTs [25]. Thus, educators need to be continuously encouraged to use e-learning technology and facilitate students with technology in improving academic learning outcomes [26].

To cover the weaknesses in the implementation of the Hybrid Learning Model and the PBL Model, it is very necessary to develop an Innovative Learning Model that can improve the learning outcomes of HOTs-based high school students. As an alternative solution that developing an Innovative Learning Model. This is in line with the findings of Hariadi's research [27] which suggests an innovative learning model that combines online learning and face-to-face learning. The innovative learning model developed is the BWML Model. The BWML model is expected to be able to improve the learning outcomes of HOTs-based high school students.

The BWML Model is a learning model that integrates the Hybrid Learning Model with the PBL Model which is supported by the use of the MoLearn application in every learning activity. The development of the model is Blended Web Mobile learning supported by the latest learning theories (constructivism, learning through 
observation, discovery learning, cognitive processes, metacognition, and scaffolding), as well as an empirical foundation from the latest research and scientific publications of researchers.

The MoLearn application is an application for Hybrid Learning that has been developed by the Dinamika University research team to improve the learning outcomes of HOTs-based high school students. In the MoLearn application, the teacher functions as a facilitator, mentor, and consultant so that students who learn to use the MoLearn application are required to learn actively. The addition of the MoLearn application with the Android version is because Mobile technology is considered an effective way to improve student skills such as positive thinking, collaborative thinking, communication, and is considered a major part of innovation in many fields of e-learning research [28]. Besides, research from Haerazi et al [29] states that learning with Mobile Apps can improve critical thinking skills in teaching writing skills.

The birth of the MoLearn application is based on the fact that current students are students in the Generation $\mathrm{Z}$ era. Among the characteristics of Generation $\mathrm{Z}$ are (1) Comfortable and highly dependent on technology, this is because Z-Generation grows surrounded by technology, (2) Multitasking with a variety of products online and sophisticated technology tools, and respect simplicity and interactive design, (3) Having a higher social responsibility with more information that can be accessed online, (4) Always connected, communicating through social networks, across countries and culture that indirectly affects the way of thinking and decision-making processes [30]. Educators must start thinking about a learning model that can align themselves with the needs of students, who always keep up with the fast development of gadgets today [31].

The description above strengthens the reasons for the need for the BWML model to improve learning outcomes for HOTs-based high school students. The main objective of this research is to produce a quality BWML model to improve HOTs-based learning outcomes. The BWML model has five phases, namely: (1) orientation based on IoTs and Big Data, (2) investigation, (3) analyzing, (4) presenting, and (5) evaluating. Each phase of the BWML model in the implementation of learning is carried out and supported by using the MoLearn application.

\section{Research Methods}

\subsection{General background}

The main objective of this research is to produce a quality BWML model (content and construct valid, reliable, and feasible/interesting). The main product in this research is the BWML model in the form of a BWML model book. Thus, this research is included in the type of development research (Research and Development). The development of the BWML model adapted Wademan's model development research design [8] [32]. The subjects in this study were high school students. The samples in this study were experts and students as the BWML user 
model. Experts perform validation regarding the content and constructs of the draft BWML model. The validity of content is the need for intervention and its design is based on current knowledge [32]. Construct validity is the fulfillment of a logically designed intervention [32]. The results of this expert's assessment are used as a reference for revising the draft BWML model. Students as users are taken from six high schools in four districts/cities in East Java Province. Students as test subjects use the BWML model learning with the MoLearn application, and after that are asked to fill out a student response questionnaire related to the application of the BWML model.

\subsection{Instrument and procedures of research}

The research instrument was a questionnaire for both experts and students which was adopted from Nieveen et al. [32]. The questionnaire for experts consists of two parts, namely (1) a questionnaire to measure the validity of content and (2) a questionnaire to measure construct validity. Questionnaire for students to measure the appropriateness or attractiveness of the BWML model of learning tools and activities. Research procedures include: (1) Preliminary research, which is carried out to obtain related data: (a) learning outcomes based on higher-order thinking skills, (b) PBL and hybrid learning models, (c) factors that support learning, (d) student and teacher opinions on learning. (2) Design the draft BWML model, which includes formulating the BWML model syntax. (3) Test the validity and feasibility of the draft BWML model. (4) Revision of the BWML model according to the test results.

\subsection{Data analysis data}

Analysis uses descriptive statistics, namely the average score of the questionnaire that has been filled in by the expert. The criteria for the mean score used the Single Measures Interrater Coefficient Correlation (ICC) and Cronbach's coefficient alpha [8] [33] as in Table 1.

Table 1. Evaluation criteria for the validity of the learning model

\begin{tabular}{|l|l|l|}
\hline \multicolumn{1}{|c|}{ Interval Score } & Criteria for Assessment & \multicolumn{1}{c|}{ Information } \\
\hline $3.30<\mathrm{P} \leq 4.00$ & Very valid & Can be used without revision \\
\hline $2.30<\mathrm{P} \leq 3.30$ & Valid & Can be used with a little revision \\
\hline $1.80<\mathrm{P} \leq 2.30$ & Less valid & Can be used with many revisions \\
\hline $1.00<\mathrm{P} \leq 1.80$ & Invalid & $\begin{array}{l}\text { Cannot be used without revision and still requires } \\
\text { consultation }\end{array}$ \\
\hline
\end{tabular}

(Adaptation: Erika et al.) [34]

This criterion is also used to analyze the quality of the developed BWML model. 


\section{$3 \quad$ Findings and Discussion}

\subsection{Rational development of the BWML model}

BWML Model built from several basic theories, namely: (1) constructivism theory, (2) learning theory through observation, (3) discovery learning theory, (4) cognitive process theory, (5) metacognition theory, and (6) multi representation theory. Each phase is implemented and supported using the MoLearn application. Emphasis on the implementation of BWML with the percentages: $70 \%$ (on the job experience), $20 \%$ (mentoring and coaching), and 10\% (classroom, course, and reading) [24] [35]. The internally organized strategy allows students to organize their thought processes, for example through investigations (phase 2: investigation). Gagne emphasized the importance of the role of cognitive strategies as one of the goals of teaching in schools. Learning how to think is also known as higher-order thinking skills. Students' knowledge of cognitive strategies in learning and thinking is an important component in achieving learning objectives, especially building HOTs-based learning outcomes. The hallmark of cognitive learning lies in learning to obtain and use representational forms (phase 2: investigation) that represent objects- the object faced, whether the object is a person, object, or event. These objects are represented or presented in a person through responses, ideas, or symbols that are all mental. The mental activity of thinking is exposed to objects that are initiated in consciousness, and physical objects as occur in observing, hearing, or feeling. Cognitive learning is closely related to the focus of this research, namely understanding the concept, which means that students must recall knowledge that has been learned in the past and utilize the potential of the environment as a learning resource.

Learning to think is faced with a problem that must be solved (phase 1: orientation), but without going through observation and reorganization in observation. The problems faced must be solved by mental operations, especially using certain concepts and rules and work methods. The ability of students to solve problems through representational work is one of the components of HOTs which is the focus of this study. Jonassen [36] and Chi, Glaser \& Farr [37] that underlies phase 1: orientation. Jean Piaget studied how children think and the processes associated with intellectual development that are innately curious and try to understand the world around them. The child needs to understand the environment by investigating and constructing a theory that explains it (phase 2: investigation). Lev Vygotsky Theories [38-39] that the basis of Phase 5: evaluation. Problem learning by John Dewey describes a view of education, with the school as a mirror of the larger society and the classroom as a laboratory for the investigation and resolution of real-life problems (phase 2: investigation) [40-41]. Bruner [42] provides theoretical support to discovery learning. When discovery learning is applied to the sciences and social sciences, Bruner emphasizes the inductive reasoning and investigative processes that characterize the scientific method (phase 3: analyzing). 


\subsection{Syntax formulation for the BWML model}

Syntax is the steps listed in the lesson plan and the steps that must be followed when the teacher implements the learning model in the classroom. BWML model has five phases, namely: (1) orientation based on IoTs and Big Data, (2) investigation, (3) analyzing, (4) presenting, and (5) evaluating. Each phase is implemented and supported using the MoLearn application. The BWML model aims to improve HOTsbased high school student learning outcomes and other goals, namely to generate motivation, activity, and student responses in learning. To achieve these goals, Model BWML was conducted through a collaborative and cooperative approach to scientific work (scientific approach), hybrid learning, application integration MoLearn, social interaction through the experience of independent study and group, and the grain problem-based contextual IoTs and Big Data. The learning objectives are explicitly contained in the syllabus and lesson plans (RPP) which are made by the teacher as general guidelines in implementing learning in the classroom. Good learning objectives are oriented specifically to students, contain a clear description of the assessment situation, and contain levels of performance achieved in the form of success criteria in learning. In general, the selection of subject matter must refer to basic competencies and predetermined indicators.

\subsection{BWML model quality and advisability assessment}

The results of the quality assessment of the BWML Model are presented in Table 3 regarding the quality of the model and Table 4 regarding the feasibility (attractiveness) of the model. Table 3 shows that the content validity and reliability of the BWML Model include: (1) The need for the development of the BWML model, (2) the State of the Art of the BWML Model, (3) The thinking framework for the formation of the BWML model, and (4) Description of the BWML learning model has a score validation mean $3.87,3.50,3.83$, and 3.67 with very valid criteria where $\mathrm{r} \alpha=.25$ and greater than $\mathrm{r}$ table, so that each component is declared valid. As for the reliability of each component with a value of $\alpha=.81$, so that each component is declared reliable. 
Table 2. The results of the analysis of the quality assessment Model BWML

\begin{tabular}{|c|c|c|c|c|c|}
\hline \multirow[b]{2}{*}{ Component } & \multicolumn{5}{|c|}{ Validity and Reliability of BWML Model } \\
\hline & $\begin{array}{l}\text { Validity } \\
\text { Score }\end{array}$ & $r_{a}$ & Validity & $\alpha$ & Reliability \\
\hline Content Validity & & & & & \\
\hline Development Needs of Learning Model BWML & 3.87 & \multirow{4}{*}{.25} & \multirow{4}{*}{ Valid } & \multirow{4}{*}{.81} & \multirow{4}{*}{ Reliable } \\
\hline State of the Art of Model BWML & 3.50 & & & & \\
\hline $\begin{array}{l}\text { Framework for Thinking the Formation of } \\
\text { Learning Model BWML }\end{array}$ & 3.83 & & & & \\
\hline Description BWML Learning Model & 3.67 & & & & \\
\hline \multicolumn{6}{|l|}{ Construct Validity } \\
\hline $\begin{array}{l}\text { Consistency of BWML Learning Model } \\
\text { development }\end{array}$ & 4.00 & \multirow{3}{*}{.20} & \multirow{3}{*}{ Valid } & \multirow{3}{*}{.75} & \multirow{3}{*}{ Reliable } \\
\hline $\begin{array}{l}\text { Thinking framework for the formation of } \\
\text { BWML Learning Model }\end{array}$ & 3.56 & & & & \\
\hline Description of Learning BWML Model & 3.67 & & & & \\
\hline
\end{tabular}

Table 2 shows that the construct validity and reliability of the BWML Model include: (1) Consistency in developing the BWML Learning Model, (2) Framework for the formation of the BWML Learning Model, and (3) Learning Description The BWML Model has an average validation score of 4.00, 3.56, and 3.67 with very valid criteria and $\mathrm{r} \alpha .20$ is greater than $\mathrm{r}$ table, so that each component is declared valid. As for the reliability of each component in terms of the $\alpha$ value, all of them are at a value of .75 , so that each component is declared reliable.

Table 3. The results of the analysis of the feasibility assessment of the BWML

\begin{tabular}{|c|c|c|c|c|c|}
\hline Component & Validity as & $\mathbf{R e}$ & liability of & BW & ML Model \\
\hline Advisability Tool & $\begin{array}{l}\text { Validity } \\
\text { Score }\end{array}$ & $\boldsymbol{r}_{\alpha}$ & Validity & $\alpha$ & Reliability \\
\hline components and learning activities & 3.42 & \multirow{7}{*}{.91} & \multirow{7}{*}{ Valid } & \multirow{7}{*}{.99} & \multirow{7}{*}{ Reliable } \\
\hline $\begin{array}{l}\text { Newness/updating of device components and learning } \\
\text { activities }\end{array}$ & 3.38 & & & & \\
\hline Ease of understanding learning device components & 3.19 & & & & \\
\hline $\begin{array}{l}\text { Ease in following the components of the process skills that } \\
\text { are trained }\end{array}$ & 3.25 & & & & \\
\hline Elements of attractiveness (fun and fun) in learning activities & 3.00 & & & & \\
\hline Teacher guidance during the learning process & 3.30 & & & & \\
\hline $\begin{array}{l}\text { The relationship between BWML model learning and } \\
\text { learning outcomes }\end{array}$ & 3.06 & & & & \\
\hline
\end{tabular}

Table 3 shows that after a large class trial was conducted, the feasibility of the BWML Model has an average validation score of 3.23 with very valid criteria and $\mathrm{r} \alpha$ $=.91$ is greater than $r$ table, so that each component is declared valid. As for the reliability of each component in terms of $\alpha$ value, all of them are at $\alpha=.99$, so that each component is declared reliable. Thus it can be said that the BWML Model can be said to be feasible and attractive to be applied in senior high school. The social system in the BWML Model refers to a learning model based on Vygotsky's constructivist [38-39]. For a learning model can still be implemented must be supported by learning 
tools and the completeness of the facilities used. The facts show that an environment that provides a conducive atmosphere for teaching and learning activities will promote good instructional delivery and better learning outcomes. The support system for a learning model is all the means, materials, and tools for implementing the BWML Model using the MoLearn application. The support system in the BWML Model uses the MoLearn application, namely: (a) Learning tools refer to the BWML Model, namely: syllabus, lesson plans, worksheets, student teaching materials (BAM), HOTsbased learning outcome evaluation instruments. (b) MoLearn application as the main support in learning. (c) Learning media in the form of virtual labs and provided computers/laptops, as well as internet networks for access to data literacy. Gadgets and games have a positive impact on the world of education [43-49]. The instructional impact of the BWML Model using the MoLearn application is that students can improve HOTs-based learning outcomes.

\section{Conclusion}

This BWML model aims to improve HOTs learning outcomes and other goals, namely to generate motivation, activity, and student responses in learning. To achieve these goals, Model BWML was conducted through a collaborative and cooperative approach to scientific work (scientific approach), hybrid learning, application integration MoLearn, social interaction through the experience of independent study and group, and the grain problem-based contextual IoTs and Big Data. The result of research shows BWML model is qualified (valid in content and constructs, and reliable) by experts. (2) The feasibility test (practically used by students) an average of 3.23 with the validity of the statistical aspects in $r \alpha=.91$ and reliability in $\alpha=.99$ This means that students claim that the model is novel and easy to use. This research implies that a quality BWML model can be used to improve HOTs-based learning outcomes. Further research can be focused on the effectiveness of the BWML model to improve HOTs-based learning outcomes.

\section{Acknowledgment}

Our gratitude goes to the President Director of the Education Fund Management Institute of the Ministry of Finance of the Republic of Indonesia who has provided Productive Innovative Research (RISPRO) funding according to the funding agreement letter number: PRJ-37 / LPDP / 2018 dated 22 November 2018.

\section{References}

[1] B. Jatmiko, B. Prahani, Munasir, Z. Supardi, I. Wicaksono, N. Erlina, P. Pandiangan, R. Athfal and Zainuddin, "The Comparison of OR-IPA Teaching Model and Problem based learning Model Effectiveness to Improve Critical Thinking Skills of Pre-service Physics 
Teachers," Journal of Baltic Science Education, vol. 17, no. 2, pp. 1-22, 2018. http://www.scientiasocialis.lt/jbse/?q=node/660 https://doi.org/10.33225/jbse/18.17.300

[2] B. Jatmiko, W. Widodo, Martini, M. Budiyanto, I. Wicaksono and P. Pandiangan, "Effectiveness of the INQF-based learning on a general physics for improving student's learning outcomes," J. Baltic Sci. Educ., vol. 15, no. 4, pp. 441-451, 2016. http://www.scientiasocialis.lt/jbse/?q=node/515 https://doi.org/10.1088/1742-6596/947/1/ $\underline{012013}$

[3] S. Prayogi, L. Yuanita and Wasis, "Critical inquiry-based learning: A model of learning to promote critical thinking among prospective teachers of physics," Journal of Turkish Science Education, vol. 15, no. 1, pp. 43-56, 2018. https://www.researchgate.net/ publication/325019447 Critical Inquiry Based Learning A Model of Learning to Pro mote_Critical_Thinking_Among_Prospective_Teachers_of_Physic

[4] J. Siswanto, E. Susantini and B. Jatmiko, "Practicality and effectiveness of the IBMR teaching model to improve physics problem-solving skills," Journal of Baltic Science Education, vol. 17, no. 3, pp. 381-394, 2018. http://www.scientiasocialis.lt/jbse/?q= node/669 https://doi.org/10.33225/jbse/18.17.381

[5] Zulkarnaen, Z. Supardi and B. Jatmiko, "Feasibility of creative exploration, creative elaboration, creative modeling, practice scientific creativity, discussion, reflection (C3PDR) teaching model to improve students' scientific creativity of junior high school," Journal of Baltic Science Education, vol. 16, no. 6, pp. 1020-1034, 2017. http://www.scient iasocialis.lt/jbse/?q=node $/ 629$

[6] Anderson and Krathwohl, A taxonomy for learning, teaching and assessing: Revision of bloom's taxonomy of educational objectives., New York: McGraw-Hill, 2001.

[7] P. Griffin and E. Care, Assessment and Teaching of 21st Century Skills: Methods and Approach, New York: Springer, 2015.

[8] P. Pandiangan, M. Sanjaya, I. Gusti and B. Jatmiko, "The Validity and Effectiveness of Physics Independent Learning Model to Improve Physics Problem Solving and Selfdirected Learning Skills of Student in Open and Distance Education System," Journal of Baltic Science Education, vol. 16, no. 5, pp. 651-665, 2017. http://www.scientiasocialis. $\underline{\mathrm{t} / \mathrm{jbse} / \mathrm{q}=\text { node/ } 601}$

[9] I. Wicaksono, Wasis and Madlazim, "The Effectiveness of Virtual Science Teaching Model (VS-TM) to Improve Student's Science Creativity and Concept Mastery on Senior High School Physics Subject," Journal of Baltic Science Education, vol. 16, no. 4, pp. 549561, 2017. www.scientiasocialis.lt/jbse/?q=node/588

[10] M. Martin, I. Mullis, P. Foy and G. Stanco, "TIMSS 2011: International Science Report," TIMSS and PIRLS International Study, Boston, 2011.

[11] M. Arizaga, A. Bahar, C. Maker, R. Zimmermen and R. Pease, "How does Science Learning Occur in the Classroom? Student's Perceptions of Science Instruction during the Implementation of REAPS Model," Eurasia Journal of Mathematics, Science \& Technology Education, vol. 12, no. 3, pp. 431-455, 2016. https://www.ejmste.com/article/ how-does-science-learning-occur-in-the-classroom-students-perceptions-of-science-instruc tion-during-4499 https://doi.org/10.12973/eurasia.2016.1209a

[12] L. Benade, Being a Teacher in the 21st Century: A Critical New Zealand Research Study, New York: Springer, 2017.

[13] M. Caesar, R. Jawawi, R. Matzim, M. Shahrill, J. Jaidin and L. Mundia, "The Benefit of Adopting a Problem Based Learning Approach on Student's Learning Developments in Secondary Geography Lessons," International Education Studies, vol. 9, no. 2, pp. 52-65, 2016. https://www.researchgate.net/publication/291998125 https://doi.org/10.5539/ies. v9n2p51 
[14] S. Chakravarthi, "Implementation of PBL Curriculum Involving Multiple Disciplines in Undergraduate Medical Education Programme," International Education Studies, vol. 3, no. 1, pp. 165-169, 2010. https://eric.ed.gov/?id=EJ1066088 https://doi.org/10.5539/ies. $\underline{\mathrm{v} 3 \mathrm{n} 1 \mathrm{p} 165}$

[15] A. Efendioglu, "Problem-Based Learning Environment in Basic Computer Course: Preservice Teacher's Achievement and Key Factor in Learning," Journal of International Education Research, vol. 3, no. 1, pp. 205-216, 2015. https://clutejournals.com/index. php/JIER/article/view/9372 https://doi.org/10.19030/jier.v11i3.9372

[16] P. Leong, "Promoting Problem-Based Learning Through Collaborative Writing," The English teachers, vol. XXXVII, pp. 49-60, 2017. http://journals.melta.org.my/index.php/ tet/article/view/295

[17] K. Kang, S. Kim, S. Kim, J. Oh and M. Lee, "Comparison of knowledge, confidence in skill performance (CSP) and satisfaction in problem-based learning (PBL) and simulation with PBL educational modalities in caring for children with bronchiolitis," Nurse Education Today, vol. 35, no. 2, pp. 315-321, 2014. https://pubmed.ncbi.nlm.nih.gov/ 25456258/ https://doi.org/10.1016/j.nedt.2014.10.006

[18] L. Kong, B. Qin, Y. Zhou, S. Mou and H. Gao, "The effectiveness of problem-based learning on development of nursing students critical thinking: A systematic review and meta-analysis," International Journal of Nursing Studies, vol. 51, no. 3, pp. 458-469, 2014. https://pubmed.ncbi.nlm.nih.gov/23850065/ https://doi.org/10.1016/j.ijnurstu.2013.06.009

[19] J. Lucky, "Motivating and empowering students' language learning in flipped integrated English classes," Flipped Instruction: Breakthroughs in Research and Practice, Vols. -, no. -, pp. 189-213, 2017. http://www.scientiasocialis.lt/jbse/?q=node/660 https://doi.org/10. 4018/978-1-5225-1803-7.ch012

[20] M. Zabit, "Problem-Based Learning on Students'Critical Thinking Skills in Teaching Business Education in Malaysia: A Literature Review," American Journal of Business Education, vol. 3, no. 6, p. 19, 2010. https://www.researchgate.net/publication/288880295 https://doi.org/10.19030/ajbe.v3i6.436

[21] O. Ates and A. Eryilmas, "Factors Effecting Performance of Tutors During Problem-Based Learning Implementation," Procedia-Social and Behavioral Science, vol. 2, no. 2, pp. 325 2329, 2010. https://www.sciencedirect.com/science/article/pii/S1877042810003708 https:// doi.org/10.1016/j.sbspro.2010.03.330

[22] L. Sern, K. Salleh, M. Mohamad and J. Yunos, "Comparison of Example-Based Learning and Problem Based Learning in Engineering Domain," Universal Journal of Educational Research, vol. 3, no. 1, pp. 39-45, 2015. https://www.researchgate.net/publication/283 185096 https://doi.org/10.13189/ujer.2015.030106

[23] G. Thompson, P. McInerney, D. Manning, N. Mapukata-Sondzaba, S. Chipamaunga and T. Maswanganyi, "Reflection of students graduating from a transforming medical curriculum in South Africa: a qualitative study," BMC Medical Education, vol. 12, no. 1, p. 49, 2012. https://www.researchgate.net/publication/228086813 https://doi.org/10.11 $\underline{86 / 1472-6920-12-49}$

[24] J. Watson, Blended Learning: The Convergence of Online and Face-to-face Education., Florida: NACOL, 2008.

[25] B. Hariadi, MD Sunarto, P. Sudarmaningtyas and B. Jatmiko, "Hybrid Learning by Using Brilian Applications as One of the Learning Alternatives to Improve Learning Outcomes in College," International Journal of Emerging Technologies in Learning, vol. 14, no. 10, pp. 34-45, 2019. https://online-journals.org/index.php/i-jet/article/view/10150 https://doi.org/ $\underline{10.3991 / \text { ijet.v14i10.10150 }}$ 
[26] M. Tubagus, S. Muslim and S., "Development of Learning Management System-Based Blended Learning Model using Claroline in Higher Education," International Journal of Interactive Mobile Technologies (iJIM), pp. 186-194, 2020. https://doi.org/10.39 91/ijim.v14i06.13399

[27] B. Hariadi, "Web-based cooperative learning, learning style, and student's learning outcomes," Educational Horizons (Cakrawala Pendidikan), vol. 34, no. 2, pp. 160-170, 2015. https://journal.uny.ac.id/index.php/cp/article/view/4821 https://doi.org/10.21831/ cp.v2i 2.4821

[28] HF El-Sofan and N. El-Haggar, "The Effectiveness of Using Mobile Learning Techniques to Improve Learning Outcomes in Higher Education," International Journal of Interactive Mobile Technologies (iJIM), pp. 4-18, 2020. https://www.researchgate.net/ publication/341523798 https://doi.org/10.3991/ijim.v14i08.13125

[29] Haerazi, IMP Utama and H. Hidayatullah, "Mobile Applications to Improve English Writing Skills Viewed from Critical Thinking Ability for Pre-Service Teachers," International Journal of Interactive Mobile Technologies (iJIM), pp. 58-72, 2020. https://www.researchgate.net/publication/341191039 https://doi.org/10.3991/ijim.v14i07. 11900

[30] JR Nichols, 4 Essential Rules of 21st Century Learning, Teach Thought, 2015.

[31] MD Sunarto, B. Hariadi, T. Amelia, T. Sagirani and J. Lemantara, "MoLearn, a Web-and Android-Based Learning Application as an Alternative for Teaching-Learning Process in High Schools," International Journal of Instruction, vol. 13, no. 1, pp. 53-70, 2020. https://www.researchgate.net/publication/338372836 https://doi.org/10.1109/mite.2018.87 47089

[32] N. Nieven, S. McKenney and V. Akker, Educational Design Research, Ner York: Routledge, 2007.

[33] N. Malhotra, Review of marketing research: Special issue-marketing legends, New York: Emerald Group Publishing Limited, 2011.

[34] F. Erika, B. Prahani, Z. Supardi and Tukiran, "Development of a Graphic Organized-Based Argumentation Learning (GOAL) Model for Improving the Ability to Argue and SelfEfficacy of Chemistry Teacher Candidates," World Trans. on Engng. and Technol. Educ., vol. 16, no. 2, pp. 179-185, 2018. https://www.researchgate.net/publication/325580448

[35] B. Woolf, Building intelligent interactive tutors: Student-centered strategies for revolutionizing e-learning, MA: Morgan Kaufmann, 2010. https://www.researchgate.net/ publication/232322117

[36] D. Jonassen, "Toward a design theory of problem-solving," Educational Technology Research and Development, vol. 15, no. 4, pp. 441-451, 2000. https://www.researchgate. net/publication/226873200

[37] M. Chi, R. Glaser, and M. Farr, The nature of expertise, New York: Psychology Press, 2014.

[38] K. Charmaz, "Grounded theory methods in social justice research," The Sage Handbook of Qualitative Research, vol. 4, pp. 359-380, 2011. https://www.researchgate.net/publication/ 301202606

[39] J. Stiglitz, Creating a learning society: A new approach to growth, development, and social progress, Columbia: Columbia University Press, 2014.

[40] J. Loughran, Developing a Pedagogy of Teacher Education: Understanding teaching \& learning about teaching, New York: Routledge, 2013. https://doi.org/10.4324/978020301 9672

[41] V. Helterbran, "Teacher leadership: Overcoming 'I am just a teacher' syndrome," Education, vol. 131, no. 2, p. 363, 2010. https://www.questia.com/read/1G1-251534611/ 
Paper-Higher Order Thinking Skills for Improved Learning Outcomes Among Indonesian Students

teacher-leadership-overcoming-i-am-just-a-teacher https://doi.org/10.3726/978-1-45391799-2/31

[42] W. Bruner, "Crack growth and the thermoelastic behavior of rocks," Journal of Geophysical Research: Solid Earth, vol. 84, no. B10, pp. 557-559, 1979. https://agupubs. onlinelibrary.wiley.com/doi/abs/10.1029/JB084iB10p05578 https://doi.org/10.1029/jb08 $\underline{4 i b 10 p 05578}$

[43] Alhalafawy, W. S., and Zaki, M. Z. T. The Effect of Mobile Digital Content Applications Based on Gamification in the Development of Psychological Well-Being. International Journal of Interactive Mobile Technologies, vol. 13 no. 8, 2019. https://onlinejournals.org/index.php/i-jim/article/view/10725 https://doi.org/10.3991/ijim.v13i08.10725

[44] Yunita, A., Nursechafia, Setiawan, E., \& Nugroho, H. (2018). The Relationship between Mobile Phone Usage in Classroom and Academic Achievement in College Life. International Journal of Interactive Mobile Technologies, vol. 12 no. 8, pp. 96-103, 2018. https://online-journals.org/index.php/i-jim/article/view/9530 https://doi.org/10.3991/ijim.v $\underline{12 \mathrm{i} 8.9530}$

[45] Fawareh, H.M.A. \& Jusoh, S. The Use and Effects of Smartphones in Higher Education. International Journal of Interactive Mobile Technologies, vol. 11 no. 6, pp. 103-111, 2017. https://online-journals.org/index.php/i-jim/article/view/7453

[46] Kalogiannakis, M., \& Papadakis, S. Evaluating pre-service kindergarten teachers' intention to adopt and use tablets into teaching practice for natural sciences. International Journal of Mobile Learning and Organisation, vol. 13 no. 1, pp. 113-127, 2019. https://www.in derscience.com/info/inarticle.php?artid=96479 https://doi.org/10.1504/ijmlo.2019.096479

[47] Papadakis, S. Evaluating pre-service teachers' acceptance of mobile devices with regards to their age and gender: a case study in Greece. International Journal of Mobile Learning and Organisation, vol. 12 no. 4, pp. 336-352, 2018. https://www.researchgate.net/publication/ 328037167 https://doi.org/10.1504/ijmlo.2018.095130

[48] Papadakis, S. Evaluating a game-development approach to teach introductory programming concepts in secondary education. International Journal of Technology Enhanced Learning, pp. 12 no. 2, pp. 127-145, 2020. https://www.researchgate.net/publi cation/338307449 https://doi.org/10.1504/ijtel.2020.106282

[49] Kalogiannakis, M., Nirgianaki, G.-M., \& Papadakis, St. 2018. Teaching magnetism to preschool children: the effectiveness of picture story reading. Early Childhood Education Journal, vol. 46 no. 5, pp. 535-546, 2018. https://www.researchgate.net/publication/ 320594185 https://doi.org/10.1007/s10643-017-0884-4

\section{$7 \quad$ Authors}

Bambang Hariadi is a Vice Rector in Student Affair. His undergraduate degree in educational administration, postgraduate and $\mathrm{Ph} . \mathrm{D}$, are consistently pursued in educational technology. He is also a researcher and lecturer in Department of Film and Television Production at Universitas Dinamika. His research interest in the education technology field, such as learning and teaching models, innovation in learning (e-learning, blended learning, mobile learning), and learning strategy. (email: bambang@dinamika.ac.id)

MJ Dewiyani Sunarto, is a researcher and lecturer in Department of Information System, Universitas Dinamika, Surabaya, Indonesia. She graduated with a Doctor in Mathematics Education. Her research interest in the education field, such as the 
utilization of technology in education, the latest learning model, and mathematics education. She is currently Head of Centre for Educational Development and Instructional Activities at Universitas Dinamika. (e-mail: dewiyani@dinamika.ac.id

Tri Sagirani, is a researcher and lecturer in Department of Information System, Universitas Dinamika. She graduated with a Bachelor of Information System, and then completed her Master's degree at the Institute Teknologi Sepuluh Nopember. Her research interest in human computer interaction, such as computer for health, learning, technology for education, technology for special education, and user experience in application computer. She is currently Head of Research and Community Service Division at Universitas Dinamika. (e-mail: tris@ dinamika.ac.id)

Tan Amelia is a researcher and lecturer in the Department of Information System, Universitas Dinamika. Her research interests include software engineering with a particular interest in requirements prioritization. She graduated from the Universitas Dinamika with bachelor's degrees in Information systems and then completed her Master's degrees in Technology Management from the Institut Teknologi Sepuluh Nopember. She is currently pursuing a Ph.D. degree with the Faculty of Computer Systems and Software Engineering, University Malaysia Pahang, Kuantan, Malaysia. (e-mail: meli@dinamika.ac.id)

Julianto Lemantara is a researcher and lecturer in the Department of Information System, Dinamika University. He graduated from STMIK Surabaya with bachelor's degrees in Information systems. He continued his study and completed his Master's degrees in Information Technology from Gadjah Mada University. He has research interests in the field of information systems, decision support systems, and data mining. Until February 2020, he has published his researches in Q2 International Journal, International Conference with Scopus Index, and Accreted National Journal (email: julianto@dinamika.ac.id)

Binar Kurnia Prahani is Doctor of Science Education. He is a researcher and lecturer in Universitas Negeri Surabaya. His research interest in the education field, such as higher order thinking skills, the utilization of technology in education, the latest learning model, and science education. (e-mail: binarprahani@unesa.ac.id)

Budi Jatmiko is a researcher and lecturer in Universitas Negeri Surabaya. He is also a professor in Department of physics, Universitas Negeri Surabaya. His research interest in the education field, such as higher order thinking skills, the utilization of technology in education, the latest learning model, and science education. (e-mail: budijatmiko@unesa.ac.id; budi@dinamika.ac.id).

Article submitted 2020-08-20. Resubmitted 2021-01-10. Final acceptance 2021-01-10. Final version published as submitted by the authors. 